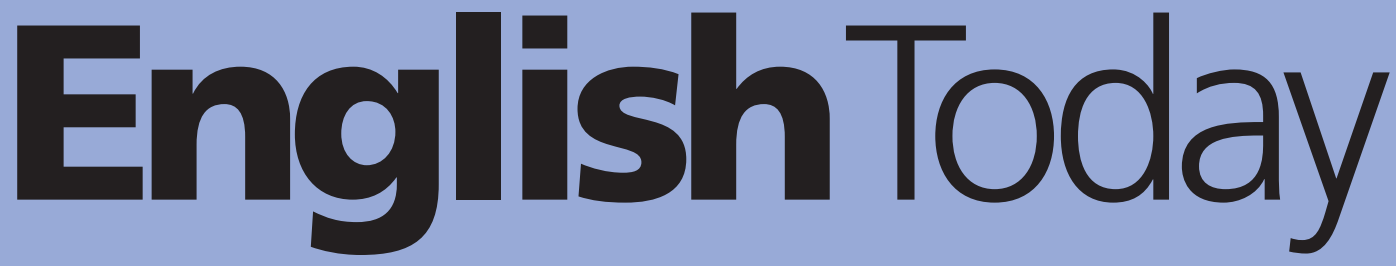

The International Review of the English Language

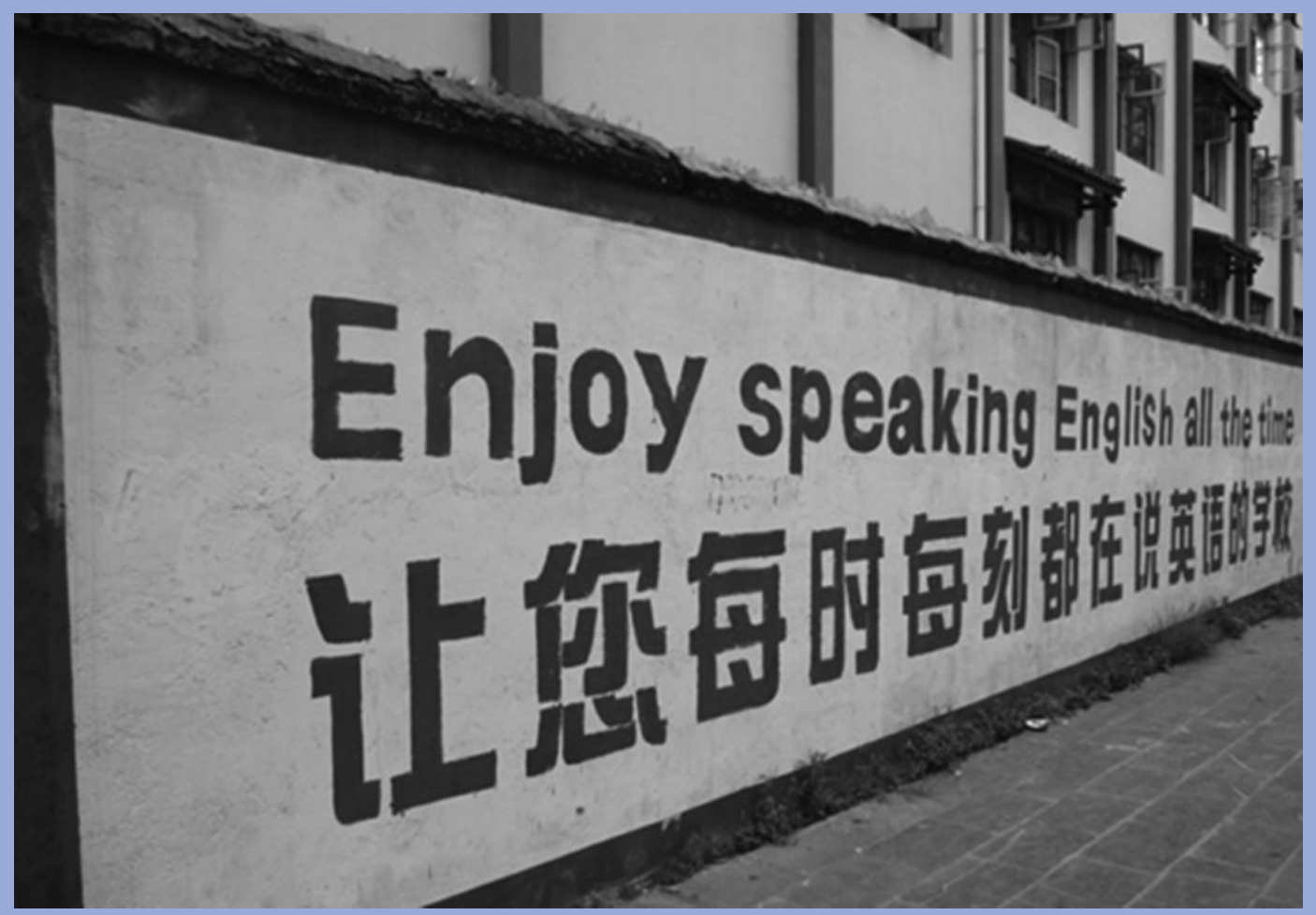

\title{
English in China Today
}

- The statistics of English in China - Creative writing by Chinese students - The crisis of English studies in Chinese universities • A threat to Chinese language and culture 


\section{English Today}

\section{The International Review of the English Language}

journals.cambridge.org/eng

Cambridge University Press

32 Avenue of the Americas

New York, NY 10013-2473, USA

Founding Editor: Tom McArthur

\section{Editors}

David Graddol, UK

Rajend Mesthrie, University of Cape Town

\section{Editorial Board}

Kingsley Bolton, City University of Hong Kong and Stockholm University

Evelyn Ch'ien, University of Minnesota, USA

David Crystal, University of Bangor, UK

Azirah Hashim, University of Malaya, Malaysia

Nobuyuki Honna, Aoyama Gakuin University, Japan

Bernd Kortmann, University of Freiburg, Germany

Merja Kytö, Uppsala University, Sweden

Andrew Moody, University of Macau, Macao, China

Salikoko S. Mufwene, University of Chicago, USA

David Nunan, University of Hong Kong, China

Anne Pakir, National University of Singapore, Singapore

Pam Peters, Macquarie University, Australia

Mario Saraceni, University of Portsmouth, UK

Barbara Seidlhofer, VOICE, University of Vienna, Austria

Loreto Todd, University of Ulster, UK

Katie Wales, University of Nottingham, UK

Catherine Walter, University of London, UK

Editorial correspondence: Sarah Rowan

englishtoday@telkomsa.net

\section{Copying}

This journal is registered with the Copyright Clearance Center, 222 Rosewood Drive, Danvers, MA 01923.

Organisations in the USA who are also registered with CCC may therefore copy material (beyond the limits permitted by sections 107 and 108 of US copyright law) subject to payment to CCC of the per copy fee of $\$ 12.00$. This consent does not extend to multiple copying for promotional or commercial purposes. Code 0261$4448 / 2012$.

Organisations authorised by the copyright Licensing Agency may also copy material subject to the usual conditions. ISI Tear Sheet Service, 3501 Market Street, Philadelphia, Pennsylvania 19104, USA is authorised to supply single copies of separate articles for private use only.
For all other use, permission should be sought from the Cambridge or New York offices of the Cambridge University Press. Information on English Today and all other Cambridge journals can be accessed via journals.cambridge.org

\section{Subscriptions}

English Today (ISSN 0266-0784) is published by Cambridge University Press four times a year in March, June, September and December. Volume 28 subscription prices including postage (excluding VAT), valid until 31 December 2012, are $£ 132$ (US \$228) for institutions print and electronic access; $£ 126$ (US \$211) for institutions print only; $£ 118$ (US \$195) for institutions electronic only; $£ 34$ (US $\$ 54$ ) for individuals print only ordering direct from the publisher and certifying that the journal is for their personal use. Single issues cost $£ 35$ (US \$58). A special rate is available for students $£ 25$ (US \$39). Special rates also apply for members of TESOL, IATEFL and other organisations. For further details, contact journals@cambridge.org

EU subscribers (outside the UK) who are not registered for VAT should add VAT at their country's rate. VAT registered subscribers should provide their VAT registration number. Orders, which must be accompanied by payment, may be sent to a bookseller or to Cambridge University Press, The Edinburgh Building, Shaftesbury Road, Cambridge CB2 8RU or in the USA, Canada or Mexico, to Cambridge University Press, The Journals Fulfillment Department, 100 Brook Hill Drive, West Nyack, New York 10994-2133. Japanese prices for institutions (including ASP delivery) are available from Kinokuniya Company Ltd, P.O. Box 55, Chitose, Tokyo 156, Japan.

Periodicals postage paid at New York, NY and at additional mailing offices. POSTMASTER: send address changes in USA, Canada and Mexico to Language Teaching, Cambridge University Press, 100 Brook Hill Drive, West Nyack, New York 10994-2133.

\section{Advertising}

Advertising queries for all parts of the world except the USA, Canada and Mexico to: ad_sales@cambridge.org Address enquiries in the USA, Mexico and Canada only to: journals_advertising@cup.org

All URLs referenced in this journal were correct approximately two months before publication.

(C) Cambridge University Press 2012 


\section{EnglishToday}

The International Review of the English Language

ET111 Volume 28 Number 3 September 2012

2 Editor's comment

3 English in China today KINGSLEY BOLTON AND DAVID GRADDOL

10 The statistics of English in China RINING WEI AND JINZHI SU

15 'Practical' English and the crisis of English studies WEIGUO QU

21 English-language creative writing by Chinese university students FAN DAI

27 Exploring pronunciation features of Yunnan English RAN AO AND EE LING LOW

34 The biggest English corner in China SHUANG GAO

40 Chinese-English code-mixing among China's netizens WEI ZHANG

53 The use of English in China's real estate advertising SONGQING LI

60 Is English a threat to Chinese language and culture? LIN PAN AND PHILIP SEARGEANT

67 Local responses to global English: perceptions of English in Taiwan HAN-YI LIN 